Jurnal Keuangan dan Perbankan, 22(1): 94-102, 2018

http://jurnal.unmer.ac.id/index.php/jkdp

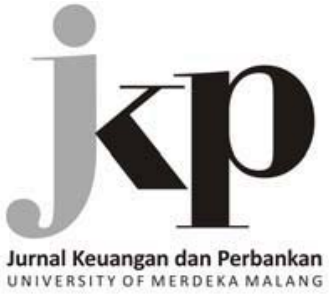

Article history:

Received: 2017-08-07

Revised: 2018-01-04

Accepted: 2018-02-28

\author{
Slamet Mulyono, \\ Djumahir Djumahir, \\ Kusuma Ratnawati \\ Department of Management \\ Faculty of Economics and \\ Business Brawijaya University \\ JI. M.T. Haryono No.165 Malang, \\ 65145 , Indonesia
}

\author{
Slamet Mulyono (Indonesia), Djumahir Djumahir (Indonesia), \\ Kusuma Ratnawati (Indonesia)
}

\section{The Effect of Capital Working Management on the Profitability}

\begin{abstract}
Companies must maintain the sustainability business. In order to keep their existence and competitiveness, companies must increase profitability in every year. It also applies to state fertilizer companies. However, 10 years of history (2005-2014), the state fertilizer company have been facing difficulties in maintaining business sustainability. Profitability fluctuates and tends to decrease every year. One of the causes is inefficient working capital management. The objective of this study is to determine the relationship between working capital management and corporate profitability. To ensure the absence of the influence of unexamined factors, this study uses control variables of firm size, financial leverage, and gross domestic product. This research uses a positivist paradigm with a quantitative approach and multiple regression analysis.The results of this study indicate that state fertilizer companies will be able to increase ROA by accelerating Days of Sales in Inventory and Days of Payables. Higher assets, reduce profitability, and increasing debt withdrawal, which further declines the profitability. State fertilizer companies should accelerate inventory turnover and obligation payments to suppliers to minimize the risk of foreign exchange loss, considering that $80 \%$ of raw materials are still imported. In addition, state fertilizer should maintain asset quality and minimize debt withdrawal to increase profitability.
\end{abstract}

Keywords: Working Capital Management, Days of Sales Outstanding, Days of Sales in Inventory, Days of Payable Outstanding, Return on Asset

\section{JEL Classification: G02; G31}

Citation: Mulyono, S., Djumahir, D., \& Ratnawati, K. (2018). The effect of capital working management on the profitability. Jurnal Keuangan dan Perbankan, 22(1), 94-102 https://doi.org/10.26905/jkdp.v22i1.1332

\begin{abstract}
Abstrak
Perusahaan harus menjaga kelangsungan usaha. Untuk menjaga eksistensi dan daya saing, perusahaan harus meningkatkan profitabilitas setiap tahunnya. Ini juga berlaku untuk perusahaan pupuknegara. Namun, dari data 10 tahun (2005-2014), perusahaan pupuk negara telah menghadapi kesulitan dalam menjaga keberlanjutan usaha. Profitabilitas berfluktuasi dan cenderung menurun setiap tahunnya. Salah satu penyebabnya adalah manajemen modal kerja yang tidak efisien. Tujuan dari penelitian ini adalah untuk mengetahui hubungan antara manajemen modal kerja dan profitabilitas perusahaan. Untuk memastikan tidak adanya pengaruh faktor yang tidak diperiksa, penelitian ini menggunakan variabel kontrol ukuran perusahaan, financial leverage, dan gross domestic product. Penelitian ini menggunakan paradigma positivis dengan pendekatan kuantitatif dan analisis regresi berganda. Hasil penelitian ini menunjukkan bahwa perusahaan pupuknegara akan dapat meningkatkan ROA dengan mempercepat jumlah hari penjualan dalam persediaan dan hutang. Aset yang lebih tinggi, mengurangi profitabilitas, dan meningkatkan penarikan utang, yang selanjutnya menurunkan profitabilitas. Perusahaan pupuknegara harus mempercepat perputaran persediaan dan pembayaran kewajiban kepada pemasok untuk meminimalkan risiko kerugian valuta asing, mengingat $80 \%$ bahan baku masih diimpor. Selain itu, pupuknegara harus menjaga kualitas aset dan meminimalkan penarikan hutang untuk meningkatkan profitabilitas.
\end{abstract}

Kata Kunci: Manajemen Modal Kerja; Days of Sales Outstanding, Days of Sales in Inventory, Days of Payable Outstanding, Return on Asset

ISSN: 1410-8089 (Print)

\section{Slamet Mulyono:}

Tel +62 2341555 000;

Fax.+62 341553834

E-mail: slamet_mulyono89@yahoo.com 
Companies must maintain the sustainability of their business, one way companies to exist and able to compete with competitors is to increase the profitability of the company each year. One of the factors that influence of achieve the company's goal is working capital management. Working capital management is an activity that involves planning and controlling current assets and current liabilities by eliminating the risk of inability to meet short-term liabilities and avoiding excessive investment in current assets of companies (Eljelly, 2004)

Empirical research on the influence of working capital management with corporate profitability has not been consistent. One of the indicators of working capital effectiveness is cash conversion cycle. In the research of (Attari \& Raza, 2012; Deloof, 2003; Karaduman, Akbas, Ozsozgun, \& Durer, 2010; Napompech, 2012; Quayyum, 2011; Tu, Tu, \& Nguyen, 2012) found the fact that cash conversion cycle has a negative relationship with profitability, or in other words by accelerating or shortening cash conversion cycle, it will be able to improve the profitability of the company. But another research conducted by (Muhammad, Jan, \& Ullah, 2012) found that cash conversion cycle has a positive relationship with profitability or its mean increased cash, inventory and credit sales will lead to increased profitability of the company.

Based on previous research results that have not been consistent between the effect of working capital management on profitability, it motivates researchers to reexamine by operationalizing days of sales outstanding, days of sales in inventory, and days of payable outstanding variables which are breakdowns of cash conversion cycle on profitability represented by return on assets, and for the results of research is not affected by factors that are not examined, then in this study using control variable, that is size company, financial leverage and gross domestic product.

The object of this research is the state fertilizer company, where the phenomenon faced by the company is the fluctuation of profitability trend and tend to decrease every year. From 10 years historical data (2005-2014) the profitability of state fertilizer as measured by Return on Asset (ROA) decreased $13.87 \%$ per year. One of the factors causing the decline in profitability is suspected to be less efficient working capital management. On the basis of the description, the purpose of this study to determine the relationship of working capital management with corporate profitablity.

\section{HYPOTHESES DEVELOPMENT}

In the current era of globalization, the emergence of competition in the business world can not be avoided anymore. An increasingly fierce competition environment needs to be observed and addressed to keep the company going concern. One of the problems faced by manufacturing companies is that much working capital is retained in accounts receivable and inventories. The problem is also faced by 5 state fertilizer companies, that their working capital is still much embedded in accounts receivable and inventory resulting in the late fulfillment or payment of current liabilities of the company.

One of the indicators of efficiency measurement of working capital is cash conversion cycle. The cash conversion cycle determinants are days of sales outstanding, days of sales in inventory and days of payable outstanding. In the research of Deloof (2003), Karaduman et al. (2010), Quayyum (2011), Attari \& Raza (2012), Napompech (2012), Tu et al. (2012), and Akoto, Awunyo-Vitor, \& Angmor (2013), stated days of sales outstanding has a negative relationship with profitability, this proves with accelerated billing receivables will be able to improve profitability. Based on the study of the concept and empirical, then the hypotheses is drawn as follows:

$\mathrm{H}_{1}$ : days of sales outstanding have a significant negative effect on return on asset. 
Days of sales in inventory is also one of the determining indicators sooner or duration of the cash conversion cycle. Accelerating or shortening days of sales in inventory will also improve profitability, as Deloof (2003), Karaduman et al. (2010), Attari \& Raza (2012), Napompech (2012), and Tu et al. (2012) found the fact that days of sales in inventory also has a negative relationship with profitability, so it can be concluded that by accelerating days of sales in inventory will save the cost of storage of raw materials, work in process and minimize damage to finished goods, thus increasing the profitability of the company. Based on the study of the concept and empirical, then the hypotheses is drawn as follows:

$\mathrm{H}_{2}$ : days of sales in inventory have a significant negative effect on return on asset.

Days of payable outstanding is influenced by fast or ever days of sales outstanding and days of sales in inventory. If the quicker withdrawal of the company's receivables and not much working capital is retained in inventory then payment of current liabilities, especially the business payables will be on time. The timely repayment of the debt can affect the profitability of the firm, according to the facts found in Deloof (2003), Karaduman et al. (2010),
Attari \& Raza (2012), and Tu et al. (2012) studies timely repayment of business debt or in other words accelerate days of payable can affect the profitability of the company. Based on the study of the concept and empirical, then the hypotheses is drawn as follows:

$\mathrm{H}_{3}$ : days of payable have a significant negative effect on return on asset.

\section{METHODS}

The design of this research is explanatory research that aims to get an explanation of the relationship between variables through hypotheses testing.

In this study because the population is limited, so it is not possible to use the sample, so that the researchers take the number of samples equal to the number of population, then the company sampled in accordance with Table 1.

Table 1. List of State Fertilizers Who Become Research Samples

\begin{tabular}{ll}
$\begin{array}{c}\text { Company } \\
\text { Code }\end{array}$ & \multicolumn{1}{c}{ Company Name } \\
\hline PKG & PT Petrokimia Gresik \\
PKT & PT Pupuk Kalimantan Timur \\
PIM & PT Pupuk Iskandar Muda \\
PKC & PT Pupuk Kujang Cikampek \\
PUSRI & PT Pupuk Sriwijaya \\
\hline
\end{tabular}

Table 2. Operational Definition of Research Variables

\begin{tabular}{|c|c|c|}
\hline Variables & Indicators & Source \\
\hline $\begin{array}{l}\text { Days of Sales } \\
\text { Outstanding }\end{array}$ & DSO $=\frac{\text { Accout Receivables }}{\text { Sales }} \times 365$ days & Karaduman et al. (2010), Quayyum (2011) \\
\hline $\begin{array}{l}\text { Days of Sales in } \\
\text { Inventory }\end{array}$ & DSI $=\frac{\text { Inventory }}{\text { Cost of Good Sold }} \times 365$ days & Karaduman et al. (2010), Quayyum (2011) \\
\hline Days of Payable & DPO $=\frac{\text { Accout Payables }}{\text { Cost Of Goods Sold }} \times 365$ days & Karaduman et al. (2010), Quayyum (2011) \\
\hline Firm Size & $\begin{array}{l}\text { SIZE = Natural Log Total Assets of the } \\
\text { Company. }\end{array}$ & $\begin{array}{l}\text { Karaduman et al. (2010), Tu \& Nguyen (2012), } \\
\text { Napompech (2012) }\end{array}$ \\
\hline $\begin{array}{l}\text { Financial } \\
\text { Leverage }\end{array}$ & $\mathrm{DER}=\frac{\text { Total Debt }}{\text { Equity of Shareholders }}$ & Tu \& Nguyen (2012), Napompech (2012) \\
\hline $\begin{array}{l}\text { Gross Domestic } \\
\text { Product }\end{array}$ & $\mathrm{GDP}=\mathrm{C}+\mathrm{I}+\mathrm{G}+(\mathrm{X}-\mathrm{M})$ & $\begin{array}{l}\text { Karaduman et al. (2010), Bilal et al. (2013), Srairi } \\
\text { (2009) }\end{array}$ \\
\hline Return On Asset & $\mathrm{ROA}=\frac{\text { Earning After Tax }}{\text { Total Asset }}$ & Quayyum (2011) \\
\hline
\end{tabular}




\section{The Effect of Capital Working Management on the Profitability}

Slamet Mulyono, Djumahir Djumahir, Kusuma Ratnawati

The operational definition of research variables shown in Table 2.

The method of analysis used is descriptive statistical analysis through multiple regression (multiple regeression). Reasons for using multiple regression to know the effect of independent variables on dependent variable with the aim to estimate and/ or predict the average the method of analysis used research is descriptive statistical analysis through multiple regeression. The reasons for using multiple regression to determine the effect of independent variables on the dependent variable in order to estimate and / or predict the average population and the dependent average value based on the value of the known independent variables. In this study, the model of regression equation used is:

$$
\begin{aligned}
Y= & -0,001+0,214 X_{D S O}-0,228 X_{D S I}-0,409 X_{D P O}- \\
& 0,297 X_{\text {SIZE }}-0,552 X_{L E V}+0,113 X_{G D P}
\end{aligned}
$$

\section{RESULTS}

The results of research hypotheses and control variables as shown in Table 3 .

Based on Table 3, the results of analysis of the influence of days of sales outstanding on return on asset showed the results of positive influence is not significant. The influence of days of sales in inventory on return on asset shows the results of significant negative effects. Based on the analysis of the influence of days of payables on return on asset shows the results of significant negative effects.

\section{DISCUSSION}

\section{The Effect of Days of Sales Outstanding on Return on Assets}

Based on the results of analysis of the influence of days of sales outstanding on return on asset showed the results of positive influence is not significant as shown in Table 3. This shows that it takes at least 3 months by state fertilizer companies to convert their receivables into cash, while the time required to convert receivables into the average cashchemical industry is 64 days.

These results reflect that the company's receivables collectibility level is still below the chemical industry average. The results of this study is not significant because the length of collection of accounts receivable is not controlled by the state fertilizer company considering $59.69 \%$ of the total trade receivables of state fertilizer companies is a receivable subsidy by the government. The ceiling of subsidy payments per year is adjusted to the fertilizer subsidy budget approved in the APBN. These results are inversely related to the results of (Deloof,

Table 3. Results of Hypotheses Testing

\begin{tabular}{cccccc}
\hline Hypotheses & Influence & Coefficient & Std. Error & t Statistics & Explanation \\
\hline 1 & $\mathrm{X}_{\mathrm{DSO}} \rightarrow \mathrm{Y}$ & 0.214 & 0.143 & 1.497 & Not significant \\
2 & $\mathrm{X}_{\mathrm{DSI}} \rightarrow \mathrm{Y}$ & -0.228 & 0.098 & -2.331 & Significant \\
3 & $\mathrm{X}_{\mathrm{DPO}} \rightarrow \mathrm{Y}$ & -0.409 & 0.166 & -2.466 & Significant \\
\hline \multicolumn{7}{l}{ The table shown the relationship between independent variables with dependent variable, with $\mathrm{T}_{\text {table }}=2,017$ and Sig. $5 \%$}
\end{tabular}

Table 4. Test Result of Control Variable

\begin{tabular}{ccccc}
\hline Influence & Coefficient & Std. Error & t Statistics & Explanation \\
\hline $\mathrm{X}_{\mathrm{SIZE}} \rightarrow \mathrm{Y}$ & -0.297 & 0.100 & -2.959 & Significant \\
$\mathrm{X}_{\mathrm{LEV}} \rightarrow \mathrm{Y}$ & -0.552 & 0.125 & -4.411 & Significant \\
$\mathrm{X}_{\mathrm{GDP}} \rightarrow \mathrm{Y}$ & 0.113 & 0.110 & 1.034 & Not significant \\
\hline
\end{tabular}

The table shown the relationship between control variables with dependent variable, with $T_{\text {table }}=2,017$ and Sig. $5 \%$ 
(2003); Karaduman et al. (2010); Tu et al. (2012); Attari \& Raza (2012); Akoto et al. (2013)

\section{The Effect of Days of Sales in Inventory on Return on Assets}

Based on the analysis of the influence of days of sales in inventory on return on asset shows the results of significant negative effects as shown in Table 3. According to Brigham \& Houston (2007), excess inventory due to slow inventory turnover rate, certainly not productive and reflects investment with the return on assets (ROA) is low or zero. The average day the state fertilizer company needs to convert its inventory into sales is 74 days or 2.5 months, while the average days of sales in inventory for chemical companies is 55 days.

The average rate of days required by state fertilizer companies to convert their inventory into sales compared to the average of chemical companies, because fertilizer companies need good raw material stock planning considering $80 \%$ of raw materials are still imported. Accelerating Days of Sales in Inventory will save the cost of raw material storage, work in process and minimize damage to finished goods, thus increasing the profitability of state fertilizer companies (Singh, Kumar, \& Colombage, 2017). Judging from the time series data, days of sales in inventory of state fertilizers experienced significant decline for the period of 2005-2014, except for PT Pupuk Iskandar Muda which tended to increase every year the impact of increasing value of urea and ammonia finished goods due to losses competing in non-subsidized retail sales in the plantation sector and low demand for ammonia by the vetsin industry.

The decrease in days of sales in inventory of state fertilizer companies is the result of efficient inventory planning and supervision that adjusts production levels and season turnover. State fertilizer companies have operational control staff who have functions to plan raw material purchases, quantum production and sales plans, so that optimal inventory quantities can be determined. The results of this study are consistent with the research conducted by Deloof (2003), Karaduman et al. (2010), Attari \& Raza (2012), Tu et al. (2012); but are inversely related to the findings of Muhammad, Jan, \& Ullah (2012).

\section{The Effect of Days of Payables on Return on Assets}

Based on the analysis of the influence of days of payables on return on asset shows the results of significant negative effects as shown in Table 3. Fulfillment of current liabilities of the company is very important in the management of working capital, because there are some current liabilities that must be met on time regardless of the company's financial condition. The higher the turnover of trade debt, the faster the company in paying the debt (Shahzad, Fareed, \& Zulfiqar, 2015).

Accounts are basically profitable for the company because it can use raw materials without having to pay in advance (Brealey \& Mayers, 2003). If the payments are slowed then this will benefit the company. If a paying company is able to postpone its debt payments without increasing operating costs, the company's profitability will be higher (Brigham \& Houston, 2007)

The average days of payables during the observation period is 189.16 days or equivalent to 6.3 months, while the average days of payables for the chemical industry is 36 days. The high days of payables of state fertilizer companies compared to the average chemical industry, due to limited working capital of state fertilizer companies. The working capital of many state fertilizer companies is embedded in accounts receivable, so for the fulfillment of current debt requires loan funds from third parties or banking. Acceptance of accounts receivable that takes a relatively long time, is an uncontrollable factor because it depends on the subsidy bud- 


\section{The Effect of Capital Working Management on the Profitability}

Slamet Mulyono, Djumahir Djumahir, Kusuma Ratnawati

get allocation in the state budget. If the company can delay the payment of short-term debt without increasing operating costs, the company's profitability will be higher. If this scenario is implicated in the state fertilizer company, the risks of increasing operating costs will increase, considering that $80 \%$ of the raw materials required by the state fertilizer companies are still imported, certainly by delaying the payment of raw material procurement to suppliers resulting in a decrease in the profitability of the company. Delayed payments to suppliers result in an increased risk of foreign exchange loss due to fluctuations and a tendency to weaken the IDR against USD. The role of financial managers is needed in maintaining cash flow and knowing the right time to pay its short obligations, thereby impacting the shortening of the cash conversion cycle and can improve the profitability of the company due to operational cost efficiency. The results of this study in accordance with research conducted by Karaduman et al. (2010).

\section{The Effect of Company Size on Return on Assets}

Based on the analysis of the effect of size on return on asset shows the results of significant negative effects as shown in Table 4. Companies with larger scale or size have easier access to obtain sources of funding from various sources, so it will be easier to obtain loans from creditors and attract investors (Wijaya, 2017). Companies with large assets will use the resources as much as possible to generate maximum business profits and companies with small assets of course also generate profits in accordance with its relatively small assets (Cristea \& Cristea, 2016).

The average total state-owned fertilizer company's assets during the observation period is Rp 10,046 trillion, which indicates that state fertilizer companies can be categorized as large companies, but the average annual increase in total assets of $12 \%$ is not matched by the quality of these assets, in most assets almost $40 \%$ is embedded in accounts receivable, on the other hand, because fertilizer companies are large companies, the ease of access to credit from creditors also affects the capital structure of state fertilizer companies. The average composition of debt of state fertilizer companies when compared to their capital during the observation period is 2 times the amount of their capital. The increase in the loan resulted from an increase in the working capital requirement of state fertilizer companies accompanied by an increase in average annual sales value of $18.86 \%$ and was not accompanied by accelerated time to convert receivables into cash. The results of this study show that firm size has a significant negative effect on return on assets, this shows that the higher asset of state fertilizer company will be able to reduce the profitability of the company and in accordance with research Martani \& Khairurizka (2009).

\section{The Effect of Financial Leverage on Return on Assets}

Based on the results of analysis of the effect of financial leverage on return on asset shows the results of significant negative effects as shown in Table 4. Financial leverage variables measured by debt to equity ratio. The higher debt to equity ratio, the greater the risk of the company because the debt raises the interest on the company so that it can reduce the profitability of the company.

The trade-off theory approach can be used as a reference to optimize the company's capital structure. The trade-off theory explains that the optimal capital structure can be achieved by balancing the tax advantage with the cost of financial distress from the addition of debt, so that the costs and advantages of adding debt in trade-offs (Brigham \& Houston, 2007). According to the trade-off theory, each firm must determine its optimal capital structure, namely the balance position between cost and benefit of funding with debt, because at that position the company's value becomes maximal (Komara, Hartoyo, \& Andati, 2016). 
The results of this study show that financial leverage significantly influence and negatively related to return on asset, or can be said with the increase of loan withdrawal, it will be able to reduce the profitability of state fertilizer companies. One of the causes of high loan withdrawals is the high working capital embedded in accounts receivable. The loan drawdown is used to finance the company's operations and development projects, in accordance with the results of the research that the average Debt Equity Ratio used as control variable is $203 \%$ or 2 times the amount of state fertilizer company's equity.

The high withdrawal of bank loans has resulted in increased borrowing costs which resulted in a decrease in corporate profitability. This has an impact on the fulfillment of raw materials financed by bank loans, reflected in the average mix of state fertilizer company financing from debt compared to own capital is $202.8 \%$. The high debt is due to $80 \%$ of raw materials needed by state fertilizer companies are still imported from Jordan, Egypt, China and Russia. This is in accordance with the theory of trade off, for that management needs to balance the capital structure, that is when the balance position between the cost and marginal profit from funding from third parties, because at this position the company's value to be maximal, so the difference between tax savings and interest costs can improve the profitability of the company.

The results of this study in accordance with research Karaduman et al. (2010) and Tu \& Nguyen (2014) and can be concluded if the withdrawal of corporate debt increased, it will increase the cost of borrowing resulting in decreased profitability of the company.

\section{The Effect of Gross Domestic Product on Return on Asset}

Based on the analysis of the effect of gross domestic product on return on asset shows the results of positive influence is not significant as shown in table 4 . The bigger Gross Domestic Product (GDP) shows the greater public expenditure or purchasing power of a country. The magnitude of the GDP rate is an opportunity for companies to produce or sell more products or services and open up the company's profit opportunities given its large community spending capabilities as well.

The measure of a country's economic success can be seen from the growth of GDP. GDP that grows sustainably means that the economy is able to produce an increasingly aggregate product through the use of optimal resources. With the increase in GDP, the unemployment rate is decreasing and the prosperity level is getting better. Without banking support, it is almost certain that the goal of achieving this prosperity is impossible (Aviliani, Siregar, Maulana, \& Hasanah, 2015)

The results showed GDP positively insignificant effect on return on asset. This is because the increase in GDP does not contribute directly to the increase in purchasing power of farmers and turnover of state fertilizer companies, given during the observation year farmers still get subsidies from the government to obtain fertilizer. Although on the other hand GDP experienced an average increase of $14.21 \%$ per year during observation period and only once decreased in 2014 impact of global crisis, but from the total increase of turnover of state fertilizer company, $80 \%$ of it is assignment of the government and the rest is an increase in sales of nonsubsidized fertilizer in the plantation sector, so it can be concluded that the main factor causing the increase in turnover of state fertilizer companies during the observation period is government policy rather than the purchasing power of the community. The results of this study are in accordance with research Srairi (2009); Karaduman et al. (2010); Bilal, Saeed, Gull, \& Akram (2013).

\section{CONCLUSION AND SUGGESTIONS}

\section{Conclusion}

Days of sales in inventory has a significant influence on the proftability of state fertilizer companies, when state enterprises are able to convert 


\section{The Effect of Capital Working Management on the Profitability}

Slamet Mulyono, Djumahir Diumahir, Kusuma Ratnawati

their inventory into sales quickly, the opportunity to increase their return on assets is also very large. Days of payables has a significant influence on the profitability of fertilizer companies, when state fertilizer companies accelerate the payment of shortterm liabilities, the risk of foreign exchange loss can be minimized so that the impact on increasing return on assets of state fertilizer companies. During the period of observation of state fertilizer company assets experienced a significant increase. The assets are dominated by accounts receivable and inventory, and it can be said that the quality is not good, so it can be followed by asset quality to increase the profitability of the company. The limited working capital due to delayed withdrawal of fertilizer subsidy has resulted in the increase of debt withdrawal by the state fertilizer company. The number of debt withdrawals has a significant influence with the profitability of state fertilizer companies. Withdrawal of debts of state fertilizer companies is high, it will have an impact on increasing borrowing costs and decreased profitability of the company.

\section{Suggestions}

State fertilizer companies are expected to accelerate days of sales in inventory to save raw material cost but considering the availability of raw material stock considering $80 \%$ of raw materials are still imported and considering production needs according to market demand.

The state fertilizer company is expected to accelerate repayment to the supplier after the subsidized government receivables are disbursed, thereby reducing the withdrawal of loans from third parties used to bail out the short-term liabilities, thereby impacting interest rate reductions and improving the profitability of the company.

State fertilizer companies need to make forward contracts to procure raw materials in order to minimize the risk of foreign exchange loss considering that $80 \%$ of raw materials required by state fertilizer companies are still imported.

\section{REFERENCES}

Akoto, R. K., Awunyo-Vitor, D., \& Angmor, P. L. (2013). Working capital management and profitability: Evidence from Ghanaian listed manufacturing firms. Journal of Economics and International Finance, 5(9), 373-379. https://doi.org/10.1007/ s40622-014-0043-3

Attari, M. A., \& Raza, K. (2012). The optimal relationship of cash conversion cycle with firm size and profitability. International Journal of Academic Research in Business and Social Sciences, 2(4), 189-203.

Aviliani, Siregar, H., Maulana, T. N. A., \& Hasanah, H. (2015). the Impact of macroeconomic condition on the bank's performance in Indonesia. Buletin Ekonomi Moneter dan Perbankan, 17(4), 24.

Bilal, M., Saeed, A., Gull, A. A., \& Akram, T. (2013). Influence of bank specific and macroeconomic factors on profitability of commercial banks: A case study of Pakistan. Research Journal of Finance and Accounting, 4(2), 2222-2847.

Brealey, R., \& Mayers, S. (2003). Principles of Corporate Finance. McGraw-Hill.

Brigham, E. F., \& Houston, J. F. (2007). Fundamentals of Financial Management (Dasar-Dasar Manajemen Keuangan).
Cristea, C., \& Cristea, M. (2016). The impact of the working capital management on firm profitability in the Romanian manufacturing industry. Annals of The Oradea University. Fascicle of Management and Technological Engineering, XXV(2), 107-110. https://doi.org/10.15660/ AUOFMTE.2016-2.3228

Deloof, M. (2003). Does working capital management affects profitability of Belgian firms? Journal of Business Finance and Accounting, 30(3), 573-587. https:// doi.org/10.1111/14685957.00008

Eljelly, A. M. A. (2004). Liquidity profitability tradeoff: An empirical investigation in an emerging market. International Journal of 
Commerce and Management, 14(2), 48-61. https://doi.org/ $10.1108 / 10569210480000179$

Karaduman, H. A., Akbas, H. E., Ozsozgun, A., \& Durer, S. (2010). Effects of working capital management on profitability: The case for selected companies in the Istanbul stock exchange (2005- 2008). International Journal of Economics and Finance Studies, 2(2), 48-54.

Komara, A., Hartoyo, S., \& Andati, T. (2016). Analisis pengaruh struktur modal terhadap kinerja keuangan perusahaan. Jurnal Keuangan dan Perbankan, 20(40), 10-21.

Martani, D., \& Khairurizka, R. (2009). The effect of financial ratios, firm size, and cash flow from operating activities in the interim report to the stock return. Serial Chinese Business Review, 8(6), 1537-1506.

Muhammad, M., Jan, W., \& Ullah, K. (2012). Working capital man- agement and profitability an analysis of firms of textile industry of Pakistan. Journal of Managerial Sciences, 6(2), 155165.

Napompech, K. (2012). Effects of working capital management on the profitability of Thai listed firms. International Journal of Trade, Economics \& Finance, 3(3), 227232.

Quayyum, S. T. (2011). Effects of working capital management and liquidity: Evidence from the cement industry of Bangladesh. Journal of Business and Technology (Dhaka), 4(1), 37-47.

Shahzad, F., Fareed, Z., \& Zulfiqar, B. (2015). Impact of working capital management on firm s profitability: A case study of cement industry of Pakistan. European Researcher, 91(2), 86-93. https:/ / doi org / 10.13187 / er.2015.91.86

Singh, H. P., Kumar, S., \& Colombage, S. (2017). Working capital management and firm profitability: A meta-analysis. Qualitative Research in Financial Markets, 9(1), 34-47. https:// doi.org/10.1108/QRFM-062016-0018

Srairi, S. A. (2009). Factors influencing the profitability of conventional and Islamic commercial banks in GCC countries. Review of Islamic Economics, 13(1), 5-30. https:// doi.org/10.1007/ s11123-009-0161-7

Tu, T. T. K., \& Nguyen, U. T. U. (2014). Relationship between working capital management and profitability - empirical evidence from Vietnamese listed firms. ICFE 2014 - The International Conference on Finance and Economics. Ton Duc Thang University, Ho Chi Minh City, Vietnam. June 2nd - 4th, 2014.

Wijaya, R. (2017). Kinerja keuangan dan ukuran perusahaan terhadap harga saham dengan kebijakan dividen sebagai variabel intervening. Jurnal Keuangan dan Perbankan, 21(3), 459-472. 